\title{
277. 耳鳴模擬音のピッチマッチ，ラウドネスバランス
}

\section{内田 郁・北原正章（滋賀医大）}

目的 耳鳴が小さくなるとピッチは低くなるもの, 不変のもの, 高くなるものといろいろあり, また, 雑 音性耳鳴のバンド幅快狭くなるものもあれば，広がる ものもあるが, これらの変化は，夷際にピッチやバン ド幅が変化したのか，あるいは耳鳴が小さくなったた めに実際には変化していないのに変化したように感じ られるのか不明である。そこでこのことを確かめるた めに，この研究では，正常人の一側耳八，3種類の大 きさの耳鳴模擬音をきかせ,他側耳で模擬音のピッチ, バンド幅を测定し，これらが模擬音の大きさによりど のように変化するのか検討し，これらのデー夕を実際 の臨床のデータ（78例117耳）と比較してみた。

方法 被検者はオージオグラムで異常を諗めない聴 力正常者 5 名で, 左耳八耳鳴模擬音をきか女, 右耳で ピッチマッチを行つた。耳鳴模擬音は低音, 中音, 高 音域の純算と雑音を用い，雑音はバンド幅の狭いもの

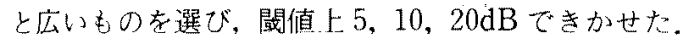

耳鳴模擬音用には $100-15000 \mathrm{~Hz}$ までの連続可変周波 数を発生できる純音発生装置 DA-502A と，2つのフ イルターで任意の中心周波数とバンド幅が得られる雑 音発生装置DA-3003，検査音用には，さらに断続音が 発生できるなど改良を加えた MODEL-3004を用い た。

結果 模擬実験では，き加せる模擬音考小さくする と，与えた周波数よりも純音では高く，雑筸では低く また，バンド幅㹥より広くピッチマッチされた。しか も実際の臨床のデータでも模擬奏験の結果に相当する ものが多くみられた。

考察 実際に㛅鳴のピッチ，バンド輻が変化する のではなく, 耳鳴の大きさが小さくなったのでピッチ はより高く，あるいはより低く，またバンド湢はより 広くなったと感じられるような症例が中にはあるので はないかと考えられた。

\section{8. 純音および語音に関する Masking Level}

\section{Difference テストの臨床的意義}

\section{下田雄丈・佐藤恒正飯塚尚久市田幸枝・河合 真 (東京警察病院)}

目的各耳に2 音同時に聴取した純音または語音と 雑䀂が形成する音像の位置の変化によるマスキング効 果の相違, すなわち Masking Level Difference (MLD) テストの診断的意義を検討した。

万法 検查音は $250 \mathrm{~Hz}$ 純音，または57式語表を，雑 音にはband，または weighted noiseを使用した。 2 台の方向感測定装置により別個に両耳間時間差を設け た検查筸と雑音が同時に形成する2音像が，共に頭蓋 中央にある場合と两唰に分離した場合の純音可聴域值

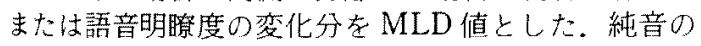
MLD值は娭者の主観が入らない自動記録法を用い た。また，全例に佐藤式方向感測定装置によって子め 方向感を測定した他に, 各種の精密恥力検查によって,

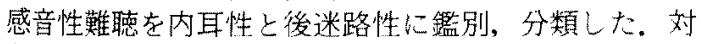
象は正常扝よび感音性難聴群, 合計64名。まず, 正常 若年者群について MLD 值の菓却限界值を算出した。 さらに，方向感の拡大の有無，抢よび内耳性上後迷路 性難㯖によってそ扎ぞ㧈 2 分し，MLDの異常例の陽 性率を検討した。

結果 (1)正常群について, $250 \mathrm{~Hz}$ 純音のMLDの枽
却限界値は6 $6 \mathrm{~dB}$ 以下であった。語音明瞭度については 分散が大きく算出しなかったが,平均值は $4.6 \%$ であ た. (2)純音のMLD 值については，正常群と感音鏶聴の 2 西群間にそれぞれ有意差を認めた( 1 \%危険率)。ま た, 感音難聴群に㧍いて, 方向感の拡大群は正常群上

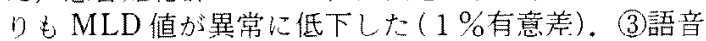
明瞙度の MLD 值については, 正常群と感音難聴群の 間に有意差を認めなかったが, 後迷路性難聴群は内耳 性難媤群よりも平均值は小であった。

結諭@方向感とMLDの测定值の間に同一の異常 傾向を認めたことは, 従来の学説に基づき, 雨者の仕 組みに共通の成立機序が存在するものと思动々る。(2) MLDテストの臨床的意義に関して，純音域值の場合 は，方向感検查同様に後迷路障害の猃断に有用である ことを追試した。しかし，語音明瞭度の場合にはさら に検討要すると結論した。留問服部浩(京都 市).SRTでは差が出るのではないか。(明瞙度では差 が出にくいと思うが）応答 今回はSRTに関し ては疲労現象考慮して施行しなかった。 